Jurnal

Kardiologi Indonesia

J Kardiol Indones. 2015;36:34-7

ISSN 0126/3773

\title{
Paroxysmal Supraventricular Tachycardia Following Ondansentron Intravenous Administration: A Case Report
}

\author{
Erick Hoetama
}

Departemen Kardiologi dan Kedokteran Vaskular Fakultas Kedokteran Universitas Indonesia, Pusat Jantung Nasional Harapan Kita
Ondasentron is selective serotonin $5-\mathrm{HT} 3$ receptor antagonist. It is widely used as the drug of choice for preventing nausea and vomiting associated with chemotheraphy and post-surgery. This drug become more popular because it's superior efficacy and minimal side effect. Although cardiovascular adverse effect caused by ondansentron administration is rare, some cardiovascular events have been reported, from atrial fibrillation to fatal ventricular tachycardia. This case reports paroxysmal supraventricular tachycardia in male 23 years old following administration of $4 \mathrm{mg}$ intravenous ondansentron.

(J Kardiol Indones. 20I5;36:34-7)

Keywords : ondansentron, adverse effects, paroxysmal supraventricular tachycardia 


\title{
Takikardia Supraventrikular Paroksismal pada Pemberian Ondansentron Intravena: Suatu Laporan Kasus
}

\author{
Erick Hoetama
}

\begin{abstract}
Ondansentron adalah antagonis reseptor serotonin 5-HT3 yang bersifat selektif. Ondansentron dipilih sebagai obat lini pertama pada penanganan kasus mual muntah pasca kemoterapi dan operasi, karena tingkat efikasinya tinggi dan efek samping yang ditimbulkan minimal. Efek samping kardiovaskular akibat pemberian ondansentron jarang terjadi, namun pada beberapa kasus dilaporkan adanya efek samping, seperti atrial fibrilasi hingga takikardia ventrikular. Pada kasus ini dilaporkan laki-laki 23 tahun mengalami takikardia supraventrikular paroksismal pasca pemberian $4 \mathrm{mg}$ ondansentron intravena.
\end{abstract}

(J Kardiol Indones. 2015;36:34-7)

Kata kunci : ondansentron, efek samping, takikardia supraventrikular paroksismal

\section{Introduksi}

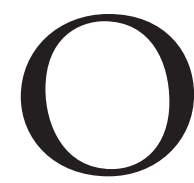

ndansentron merupakan antagonis reseptor serotonin 5-HT3 selektif yang sering digunakan untuk mencegah mual dan muntah pada pasien postoperasi, kemoterapi, dan radiasi. Ondansentron menghambat reseptor 5-HT3 pada neuron vagal aferen yang menginervasi saluran gastrointestinal dan di pusat muntah. ${ }^{1}$ Penggunaan ondansentron umumnya ditoleransi dengan baik karena efeknya yang poten dan jarang menimbulkan efek samping

\section{Alamat Korespondensi}

dr. Erick Hoetama, RSUD dr. Haji Marsidi Belitung. Tel. 081291005745. E-mail: erick.hoetama@gmail.com yang bermakna. Efek samping kardiovaskular yang pernah dilaporkan, antara lain : takiaritmia (ventrikular takikardia, supraventrikular takikardia, atrial fibrilasi), bradikardia, AV blok, pemanjangan interval QT, hingga iskemia miokardial. ${ }^{2-4}$

\section{Laporan Kasus}

Seorang laki-laki berusia 23 tahun datang ke UGD Rumah Sakit Umum Daerah Ruteng dengan keluhan nyeri perut kanan bawah sejak dua hari sebelum masuk rumah sakit. Pasien kemudian didiagnosis sebagai apendisitis akut dan direncakan untuk tindakan apendektomi. Pasien tidak mempunyai riwayat penyakit kardiovaskular sebelumnya, tidak memilki riwayat alergi sebelumnya, dan tidak sedang mengonsumsi obat-obatan apapun. Riwayat merokok, 
dan konsumsi alkohol disangkal. Induksi anastesi menggunakan propofol $125 \mathrm{mg}$, ketamine $50 \mathrm{mg}$, dan vecuronium $0.5 \mathrm{mg}$. Anastesia dipertahankan dengan isoflurane Minimum Alveolar Concentration (MAC) 1\%, oksigen 2 liter per menit, dan N2O 3 liter per menit. Pasien lalu diberikan injeksi cefotaxime 2 gram sebelum insisi dilakukan. Operasi berlangsung kurang lebih satu jam. Setelah operasi pasien sadar dan tanda vitalnya adalah tekanan darah $120 / 80 \mathrm{mmHg}$, nadi 82 kali per menit, pernapasan 16 kali per menit, dan suhu $37.2^{\circ} \mathrm{C}$. Pada pasien lalu diberikan injeksi ondansentron $4 \mathrm{mg}$ untuk mencegah keluhan mual dan muntah pasca operasi. Lima menit berselang pasien tiba-tiba mengeluh dadanya berdebar, dan terasa ingin pingsan. Keluhan nyeri dada, dan sesak napas disangkal. Tekanan darah $140 / 90 \mathrm{mmHg}$, nadi teraba sangat cepat, pernapasan 24 kali per menit, dan saturasi oksigen 95\%. Pemeriksan elektrokardiogram (EKG) menunjukan gambaran takikardia dengan kompleks QRS sempit, laju QRS nampak reguler dengan frekuensi 166 kali per menit. (Gambar 1). Pada pasien segera diberikan oksigen via nasal kanul dan dilakukan pemijatan nadi karotis selama 5 menit. Setelah 5 menit, frekuensi nasi menjadi 124 kali per menit. Karena adenosin tidak tersedia, dilakukan pemijatan nadi karotis pada sisi kontralateral dengan waktu yang sama. Frekuensi nadi tidak mengalami perubahan, namun pasien tidak lagi merasa jantungnya berdebar, dan keluhan ingin pingsan sudah tidak dirasakan lagi. Pasien diobservasi selama dua hari di ruang rawat inap. Selama observasi dilakukan pemeriksaan fungsi tiroid, dan hasilnya dalam batas normal. Selanjutnya pasien dipulangkan tanpa adanya komplikasi apapun.

\section{Diskusi}

Reseptor 5-HT3 terdapat paling banyak di area postrema, nukleus traktus solitarius, dan neuron aferen terminal dari nervus vagal. Seperti yang telah disebutkan sebelumnya, odansentron bekerja selektif untuk menghambat reseptor 5-HT3 tersebut, baik yang terletak di sentral maupun perifer. Penggunaan ondansentron umumnya terbatas pada penanganan kasus mual muntah pasca kemoterapi atau radiasi. Tingkat efikasinya yang tinggi, efek samping serta interaksi obat yang minimal membuat ondansentron menjadi obat lini pertama pada kasus tersebut. ${ }^{1}$ Meskipun sangat jarang menimbulkan efek samping yang serius, terdapat beberapa laporan mengenai efek samping ondansentron pada sistem kardiovaskular. William et al. melaporkan timbulnya aritimia berupa bigemini dengan depresi segmen ST, dan sinus bradikardia yang diikuti irama junctional dengan denyut lolos ventrikel pada pasien yang diberikan $4 \mathrm{mg}$ ondansentron intravena. ${ }^{5}$ Nagesha et al. melaporkan kasus atrial fibrilasi pasca pemberian ondasentron dengan dosis serupa. ${ }^{3}$ Pada dua laporan lain didapatkan kasus takikardia ventrikuler dan bradikardia simptomatik disertai henti napas dan kehilangan kesadaran setelah pemberian ondansentron. ${ }^{2,4}$ Disamping potensi aritmogeniknya, penggunaan ondansentron juga dilaporkan dapat mencetuskan episode angina terkait iskemia miokardial. ${ }^{3}$

Efek serotonin pada sistem kardiovaskular sangat kompleks dan belum sepenuhnya dipahami. Efek yang ditimbulkan dapat berupa bradikardia, takikardia, hipotensi, hipertensi, vasokontriksi,

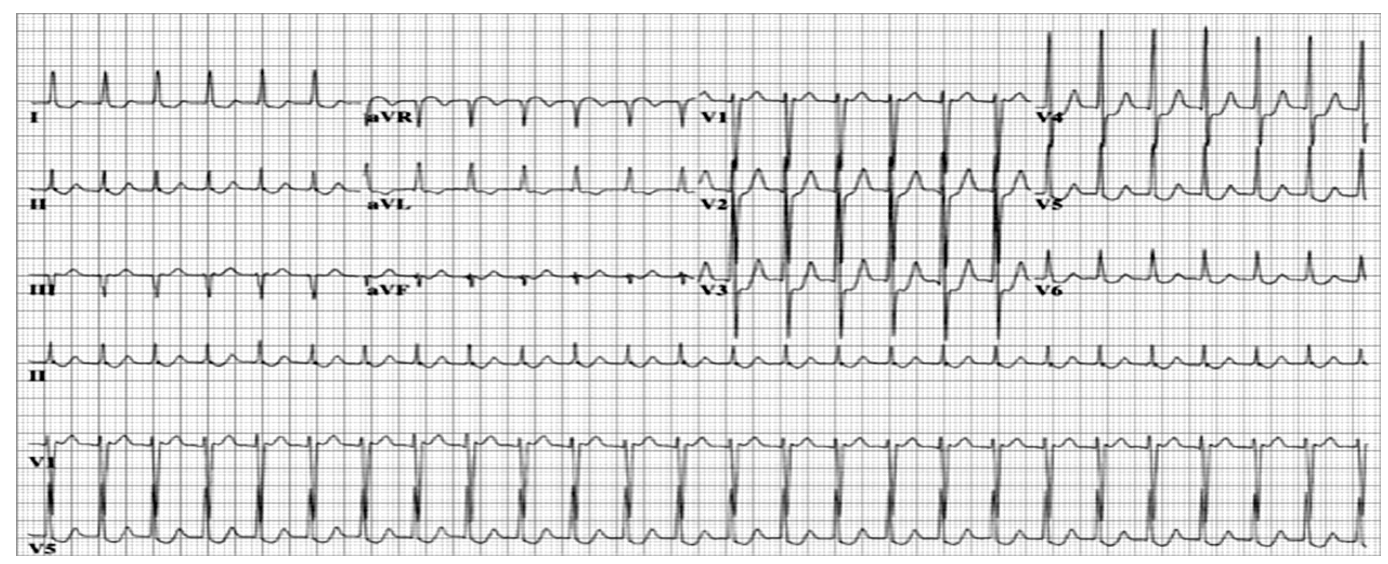

Gambar 1. Gambaran elektrokardiogram pasien menunjukan takikardia regular dengan QRS sempit dan laju jantung 166 kali per menit. Pada sadapan II dan III nampak gelombang P retrograd. Pada sadapan V1 nampak pseudo r'. 
maupun vasodilatasi. Seluruh efek tersebut berkaitan dengan empat tipe reseptor yang tersebar di sistem kardiovaskular, yaitu 5-HT1, 5-HT2, 5-HT3, dan 5-HT4. ${ }^{6}$ Aktivasi reseptor 5 -HT3 berperan pada refleks Bezold-Zarich, yakni refleks otonom yang dapat menyebabkan bradikardia, hipotensi, dan apneu. Refleks Bezold-Zarich sering dihubungkan dengan kejadian sinkop vasovagal. Aktivasi tiga reseptor lainnya, yakni 5-HT1, 5-HT2, dan 5-HT4 sebaliknya dapat mencetuskan takikardia, dan hipertensi. ${ }^{3}$

Terdapat beberapa mekanisme yang menjelaskan bagaimana ondansentron dapat mencetuskan aritimia jantung. ${ }^{3,7}$ Mekanisme yang pertama berhungan dengan perubahan pada elektrofisiologi normal jantung. Seperti yang sudah diketahui, kanal natrium $\left(\mathrm{Na}^{+}\right)$dan kalium $\left(\mathrm{K}^{+}\right)$berperan penting pada proses pembentukan aksi potensial di jantung, yakni fase depolarisasi dan repolarisasi. Fase depolarisasi ventrikel digambarkan sebagai kompleks QRS pada EKG. Fase repolarisasi terjadi aktibat aktivasi dua jenis kanal $\mathrm{K}^{+}$, yaitu rapid repolarising current $\left(\mathrm{I}_{\mathrm{KR}}\right)$ dan slow repolarising current $\left(\mathrm{I}_{\mathrm{KS}}\right)$. Kedua kanal ini masing-masing menyebakan fase repolarisasi cepat dan lambat, dan berperan penting pada pembentukan interval QT. Ondansentron menghambat kanal $\mathrm{K}^{+}$tipe $\mathrm{I}_{\mathrm{KR}}$ yang dikodekan oleh human ether-a-go-go-related gene (HERG), sehingga berakibat pada pemanjangan fase repolarisasi refrakter. Antagonis serotonin yang lain seperti granisetron, dolasetron, tropisetron, dan palonasetron memiliki efek pada kanal $\mathrm{Na}^{+}$dan $\mathrm{K}^{+}$, sehingga dapat terjadi pelebaran kompleks QRS atau pemanjangan interval QT. Akibatnya dapat terjadi aritmia ventrikular. Mekanisme yang kedua berkaitan dengan efek antagonis selektif ondansentron pada reseptor 5-HT3. Inhibisi reseptor 5-HT3 mengakibatkan supresi pada refleks Bezold-Zarich, sehingga berpotensi memicu terjadinya takiaritmia. Disamping itu, inhibisi reseptor 5-HT3 bisa menyebabkan aktivasi berlebihan dari reseptor serotonin yang lain, yakni 5-HT1, 5-HT2, dan 5-HT4, sehingga dapat terjadi takiaritmia dan hipertensi. ${ }^{7}$

Penyebab takikardia supraventrikular pada kasus ini kemungkinan besar disebabkan oleh pemberian ondansentron intravena. Hasil pemeriksan fisik dan penunjang yang normal, serta tidak adanya riwayat penyakit kardiovaskular maupun keluhan terkait sistem kardiovaskular sebelumnya menunjang hal ini. Obat-obatan lain yang digunakan seperti propofol, vecuronium, isoflurane dan cefotaxime tidak memiliki hubungan dengan takiaritmia yang dialami pasien.
Faktor perancu pada kasus ini adalah pemberian ketamine. Ketamine merupakan analgetik yang bersifat simpatomimetik dengan durasi kerja 1-2 jam. Pemberian ketamine dapat menyebakan peningkatan tekanan darah, dan takikardia. ${ }^{8}$ Meskipun demikian, efek tersebut umumnya terjadi pada dua menit setelah pemberian dan berangsur menghilang dalam 15-20 menit. Di samping hal-hal yang telah disebutkan sebelumnya, penyebab lain seperti idopatik tidak dapat disingkirkan sepenuhnya. ${ }^{9}$

Sebagai kesimpulan, ondansentron sebagai antagonis selektif reseptor 5-HT3 memiliki efek samping pada sistem kardiovaskular yang perlu diwaspadai. Efek yang ditimbulkan sangatlah beragam tergantung pada aktivitas serotogenik sistem syaraf otonom masing-masing individu. Pengawasan EKG selama pemberian ondansentron intravena perlu dipertimbangkan.

\section{Daftar Pustaka}

1. Tyres MB, Freeman AJ. Mechanism of the anti-emetic activity of 5-HT3 receptor antagonists. Oncology 1992;49(4):263-8.2.

2. Chandrakala R, Vijayashankara CN, Kumar KK, Sarala N. Ondansentron induced fatal ventricular tahcycardia. Indian J Pharmacol 2008;40(4): 186-187.

3. Kasinath NS, Malak O, Tetzlaff J. Atrial fibrillation after ondansetron for the prevention and treatment of postoperative nausea and vomiting: a case report.Can J Anaesth 2003;50(3):229-31

4. Moazzam MS,Nasreen F, Bano S, Amir SH. Symptomatic sinus bradycardia: A rare adverse effect of intravenous ondansentron. Saudi J Anaesth 2011;5(1):96-97.

5. Baguley WA, Hay WT, Mackie KP, Cheney FW, Cullen BF. Cardiac Dysrhythmias Associated with the Intravenous Administration of Ondansetron and Metoclopramide. Anesth Analg 1997; 84:1380-1.

6. Saxena PR, Villalon CM. Cardiovascular effects of serotonin agonists and antagonists. J Cradiovasc Pharmacol 1990;15(7):1734.

7. Kuryshev YA, Brown AM, Wang L, Benedict CR, Rampe D. Interactions of the 5-hydroxytryptamine 3 antagonists class of antiemetic drugs with human cardiac ion channels. J Pharmacol Exp Ther 2000;295:614-20.

8. Waxman K, Shoemaker WC, Lippman M. Cardiovascular Effects of Anesthetic Induction with Ketamine. Anesth Analg 1980;59:355-358.

9. Craven R, Alkhafaji R. Ketamine in Anaesthetic Practice. \{cited: Desember 2014\}. Available from : http://www.frca.co.uk/article. aspx?articleid $=100644$. 